The Geological Society of America

Digital Map and Chart Series 10

2012

\title{
Notes on a Map of the 1961-2010 Eruptions of Volcán de Pacaya, Guatemala
}

\author{
Ruben Otoniel Matías Gomez \\ William I. Rose \\ José Luis Palma* \\ Rüdiger Escobar-Wolf \\ Michigan Technological University, Houghton, Michigan 49931, USA
}

\begin{abstract}
A database of geologic units emplaced during the eruptions of the Volcán de Pacaya, Guatemala, from 1961 to 2010, has been compiled in a geographic information system (GIS). The mapping of the units is based on integrating information from aerial photographs, satellite images, and detailed field observations. The information consists of a total of 249 lava flow units, six pyroclastic flow units, two scoria-fall units, two undivided pyroclastic units (proximal and distal), one aeolian sediments unit, and one alluvium unit, all of which are defined as polygons in the GIS. A total of 349 eruptive vents associated with flow units were also identified and defined as points in the GIS. Volumes were calculated for all lava flows, yielding a cumulative volume of $0.078 \mathbf{~ k m}^{3}$ (not corrected for density). The volumes of four tephra deposits related to explosive events during this period were also calculated, and yielded values of the order of $10^{6}$ to $>10^{7} \mathrm{~m}^{3}$ each. Geochemical data of 69 samples of lava show that the composition of erupted products did not change systematically, with $\mathrm{SiO}$, ranging from 50 to $52.5 \mathrm{wt} \%$. The GIS information is organized in geologic units, coded by date of emplacement between 1961 and 2010, and is presented in eight geologic maps, showing the units exposed at the surface at different intervals of time. Altogether, this unique data set documents the 50-yr-long effusive and explosive activity associated with the growth of a basaltic stratocone. These data can be used, for instance, to study the morphological aspects of cone building at polygenetic volcanoes, and the behavior of lava flows.
\end{abstract}

\section{INTRODUCTION}

Geologic maps of active volcanoes are a fundamental source of information necessary to address a broad set of geological questions, such as the style and frequency of volcanic activity, its products, and associated hazards (Scott, 1989; Escobar-Wolf

*Current address: Department of Geology, University at Buffalo, Buffalo, New York 14260, USA. et al., 2009). Pacaya volcano, located $30 \mathrm{~km}$ south of the capital city of Guatemala, has shown continual Strombolian activity and extrusion of lava since the start of its last eruptive cycle in 1961. Since 2004, and after 3 years of quiescence, the activity at Pacaya has been characterized by mild explosive activity concentrated at the summit crater and lava flows extruding on the north and west flanks of the active cone.

Pacaya is surrounded by several communities, including El Caracol, El Rodeo, El Patrocinio, San Francisco de Sales, and

Matías Gomez, R.O., Rose, W.I., Palma, J.L., and Escobar-Wolf, R., 2012, Notes on a Map of the 1961-2010 Eruptions of Volcán de Pacaya, Guatemala: Geological Society of America Digital Map and Chart Series 10,10 p., doi:10.1130/2012.DMCH010. For permission to copy, contact editing@ geosociety.org. @ 2012 The Geological Society of America. All rights reserved. 
San José Calderas, with a total population of $\sim 10,000$ people who live less than $5 \mathrm{~km}$ from the active cone. The volcano and surroundings were declared a national park in 1963 ("Parque Nacional del Volcán de Pacaya", http://volcandepacaya.com, 2010). The volcano's activity has been a source of income for the local population through the development of tourism, attracting visitors from around the world. For instance, the Amatitlán geothermal field was developed nearby and was planned for an initial $20 \mathrm{MW}$ capacity, with the possibility to expand it up to $50 \mathrm{MW}$ in the future. The proximity of populated centers and energy infrastructure to an erupting volcano raises concerns over the risks associated with volcanic activity. This is illustrated by the recurrent evacuations of the population from towns near the volcano during recent eruptions (Witham, 2005; Venzke et al., 2009).

This paper presents the methodology and results of a detailed mapping of lava flow units, pyroclastic deposits, and active vents associated with the activity of Pacaya between 1961 and 2010. The results include length, area, and volume of the lava flows, along with their average emission rate, which was calculated based on their observed duration. In addition, new geochemical data of Pacaya's eruptive products (2000-2009) have been combined with previous analysis in order to present a complete data set for the period of study.

\section{GEOLOGIC SETTING AND PAST ACTIVITY}

The Pacaya volcanic complex is part of the Central America volcanic arc, which is associated with the subduction of the Cocos plate under the Caribbean plate (Mann et al., 2007; Fig. 1). Located on the southern rim of the Amatitlán Caldera, this complex includes the Pacaya composite cone, Cerro Grande and Cerro Chiquito, and the Cerro Chino scoria cone (Eggers, 1971). These eruptive centers have been active during the Quaternary and have produced olivine-bearing basaltic lavas; pyroxene andesites, dacites and rhyodacites; and associated pyroclastic products (Eggers, 1971; Bardintzeff and Deniel, 1992). Based on the paleomagnetic analysis of lavas, Conway et al. (1992) showed that the volcanism at Pacaya has been strongly episodic, with eruptive intervals lasting 100 to more than $300 \mathrm{yr}$, and quiescent periods lasting typically between 300 and $500 \mathrm{yr}$.

Eggers (1971) characterized the eruptive history of the Pacaya volcanic complex in three phases. Phase I was a period of andesitic volcanism marked by the growth of small stratovolcanoes. Phase II produced several voluminous rhyodacite and andesite dome-forming eruptions. Phase III was characterized by basaltic lava flows and the growth of a stratocone, the "Old Pacaya." During this phase the southwest slope up to the summit collapsed leaving an arcuate scarp. Kitamura and Matías (1995) inferred that the last eruptive episode of Phase III started between 700 and 3000 yr B.P., after a repose time of 1000-2000 yr. Vallance et al. (1995) asserted an age of between 400 and $2000 \mathrm{yr}$ B.P. for the collapse of "Old Pacaya," based on the thickness of the soil developed on the debris avalanche deposit, and the lack of any account of such an event in the historical written record which

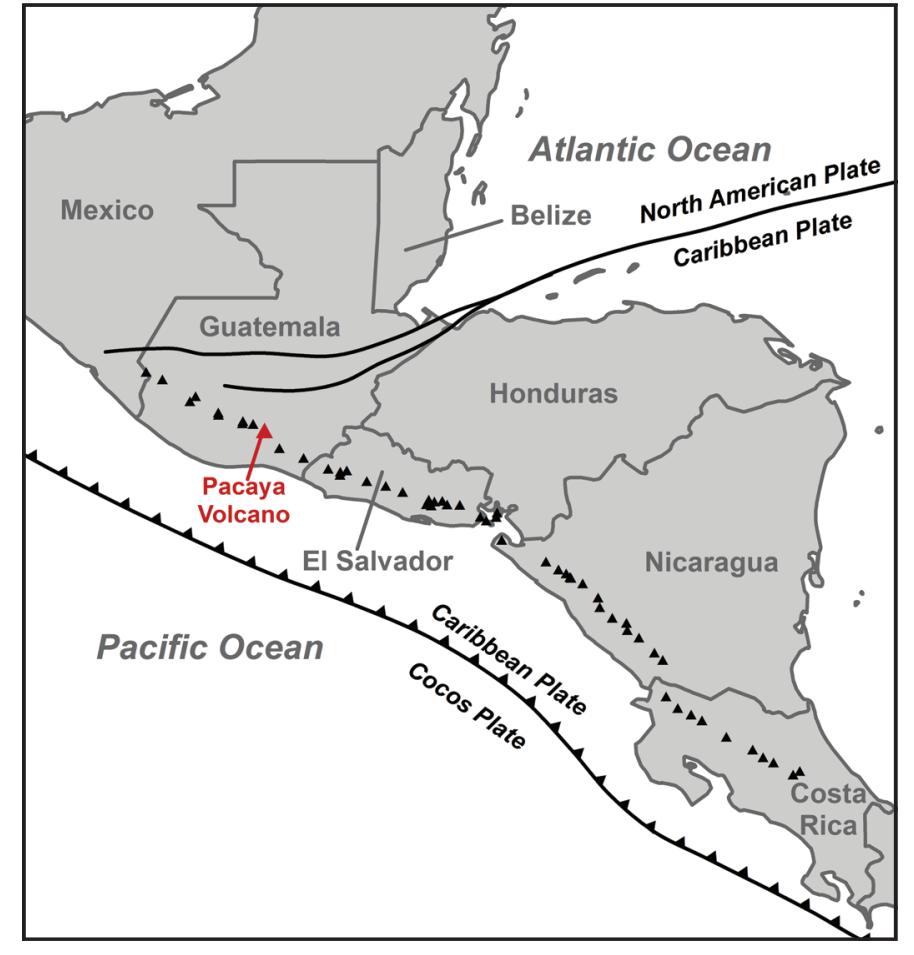

Figure 1. Location map of Volcán de Pacaya in the volcanic front of Guatemala. Other volcanoes of the Central American volcanic arc are shown as black triangles.

started in the sixteenth century. The calibrated ${ }^{14} \mathrm{C}$ dates of two fall units by Kitamura and Matías (1995) at 1500 yr B.P. and $\sim 600 \mathrm{yr}$ B.P. suggest that the collapse was confined to that age range (equivalent to $\sim 500-1400$ C.E.). During the historic period, extensive basaltic lava flows and tephra layers were deposited. This activity included the creation of the Cerro Chino scoria cone on the northwest rim of the scarp, and the modern cone of Pacaya (Eggers, 1971).

The structure of the composite cone of the modern Pacaya volcano, built inside the collapse amphitheater of "Old Pacaya," is a sequence of lava flows, scoria and tephra layers, and pyroclastic flow deposits. The current Pacaya summit is formed by two overlapping cones, the first cone built after the collapse of "Old Pacaya" in the nineteenth century (Eggers, 1971; Venzke et al., 2009). The activity restarted in 1961 with a long lava flow eruption on the lower parts of the south flank of the first cone. The second cone, known as the Mackenney cone, started to grow in 1965 on the west flank of this cone. From 1961 to 2009, activity was restricted to the interior of the collapse amphitheater, but that changed in 2010 (see map unit Hb10). Beginning in 2006, accumulation of lava next to the scarp wall on the north side of the active cone overcame this topographic barrier. An eruption on 27 May 2010 produced extensive tephra fall north of the volcano, blanketing Guatemala City with several millimeters of tephra. Ballistic bombs ejected by the eruption also impacted the communities to the north and up to $\sim 3.5 \mathrm{~km}$ from the vent. This 
activity was followed by the emplacement of an extensive lava flow field over the following two weeks, and this flow (Hb10) was vented outside of the collapse amphitheater.

\section{FLOW UNITS ERUPTED, 1961-2010}

\section{Information Sources}

Several sources of information were utilized to identify and delineate the extension of lava flows and pyroclastic deposits: aerial photographs, Landsat satellite images; high resolution orthophotographs; unpublished descriptions of the volcanic activity by Alfredo Mackenney; unpublished field reports and volcanic activity bulletins from the Guatemalan National Institute of Seismology, Volcanology, Meteorology and Hydrology (INSIVUMEH); and activity reports from the Global Volcanism Program of the Smithsonian National Museum of Natural History (GVP-SNMNH, Venzke et al., 2009). Additionally, field surveys were undertaken in January-February 2009, July 2010, and January 2011, in order to scrutinize the distribution of some deposits, and to complete the map with the recent lava flow units emplaced between 2005 and 2010. Eruptive vents were also identified and included in the map. The final map required the integration of all these data into a Geographic Information System (GIS) in ArcMap (ArcGIS, ESRI ${ }^{\circledR}$ ).

1. Aerial and satellite images: Aerial photographs were scanned at a 600 dpi resolution, on a 256 shades of gray scale. Orthorectified and georeferenced photographs from 2005-2006 were taken as a cartographic base; common points were identified on both the scanned aerial photographs and the orthophotos in the cartographic base, and used for georeferencing (Tables 1 and 2). For accurate georeferencing, several different adjustment methods were used in order to find the one that was best suited to each case (e.g., polynomial fitting from first to third order, spline fitting, etc.). This was achieved using the georeferencing fitting toolbox in ArcMap ${ }^{\circledR}$. High resolution ( 0.5 and $2 \mathrm{~m}$ pixel size) orthophotographs acquired in 2000 and in 2005-2006 were used to digitize polygons corresponding to several units. More than 700 Landsat satellite images (Landsat 1-3 MSS, Landsat 4-5 MSS, Landsat 4-5 TM, Landsat 7SLC_On, Landsat SLC_Off, Landsat 5-7 Combined-Sensor Type, and Landsat 7) were inspected, but only 16 were selected between 1986 and 2001 as useful sources of information to recognize, identify, and date the mapped units (Table 3).

2. Field data: Field notes and daily reports from the Pacaya Volcanological Observatory (OVPAC), and daily volcanological bulletins from the Volcanology Unit of INSIVUMEH, collected since 1987, were used to recognize, identify, delineate, and date 93 polygons of lava flow and pyroclastic flow units. The information published by GVP-SNMNH (Venzke et al., 2009) was used to confirm dates of eruptions and to delineate 10 lava flow units.

3 . In addition, field surveys carried out in January and February of 2009, July 2010, and January 2011 allowed the identification and delineation of 9 lava flow units and one pyroclastic flow unit deposited between 2005 and 2010. Foot surveys were performed along the boundaries of all these units using two handheld GPS (GARMIN GPS72). Only GPS locations showing an error of less than $5 \mathrm{~m}$ were used.

\section{DIGITAL DATA SET}

All the geological units were digitized as polygons and the eruptive vents as points, both in ESRI ${ }^{\circledR}$ shapefile. The digital images were georeferenced to the Guatemala Transverse Mercator

TABLE 1. NON-ORTHORECTIFIED AERIAL PHOTOGRAPHS THAT WERE GEOREFERENCED

\begin{tabular}{|c|c|c|c|c|}
\hline Numbers & Line & Project/Location & $\begin{array}{l}\text { Approximate } \\
\text { scale }\end{array}$ & $\begin{array}{c}\text { Date } \\
\text { (mm/dd/yyyy) }\end{array}$ \\
\hline $427-429$ & L-018 & SNA NIMA / Guatemala & $1: 40,000$ & $01 / 22 / 2000$ \\
\hline $111-114$ & R115, L-3 & Lago de Amatitlán & $1: 25,000$ & 07/09/1982 \\
\hline $001-003$ & R-102, L10A & Guatemala City & $1: 30,000$ & 01/16/1981 \\
\hline $1-5$ & $\mathrm{R} 160 \mathrm{~A}$ & Pacaya volcano & $1: 10,000$ & $01 / 14 / 1963$ \\
\hline $2,5,9$ & $\mathrm{R} 161$ & Pacaya eruption & $1: 7,000$ & 04/12/1961 \\
\hline 110,111 & R666ZA, L-114e & & $1: 30,000$ & 1962 \\
\hline 620,621 & W, WWS, M7 & AMS & $1: 30,000$ & $01 / 28 / 1954$ \\
\hline
\end{tabular}

TABLE 2. AERIAL ORTHORECTIFIED AND GEOREFERENCED PHOTOGRAPHS

\begin{tabular}{lcccr}
\hline \hline ID & Date & $\begin{array}{l}\text { Resolution } \\
\text { (pixel size) }\end{array}$ & Type & Source \\
\hline $2052-I I-18$ & Nov. 2005-Apr. 2006 & 0.5 meters & Color & IGN \\
$2052-I I-19$ & Nov. 2005-Apr. 2006 & 0.5 meters & Color & IGN \\
$2052-I I-23$ & Nov. 2005-Apr. 2006 & 0.5 meters & Color & IGN \\
$2052-I I-24$ & Nov. 2005-Apr. 2006 & 0.5 meters & Color & IGN \\
$2052-I I-18$ & January 2000 & 2 meters & B/W & IGN/JICA \\
$2052-I I-19$ & January 2000 & 2 meters & B/W & IGN/JICA \\
$2052-I I-23$ & January 2000 & 2 meters & B/W & IGN/JICA \\
$2052-I I-24$ & January 2000 & 2 meters & IGN
\end{tabular}

Notes: B/W-black and white; IGN/JICA-Instituto Geográfico Nacional-Japanese International Cooperation Agency. 
TABLE 3. LANDSAT SATELLITE IMAGES USED (LAT $14.5^{\circ} \mathrm{N}$, LONG $90.8^{\circ} \mathrm{W}$ )

\begin{tabular}{lcc}
\hline \hline ID & Type & Date $(\mathrm{mm} / \mathrm{dd} / \mathrm{yyyy})$ \\
\hline LT50200501986072XXX07 & TM & $04 / 14 / 1986$ \\
LT40200501988310XXX12 & TM & $11 / 05 / 1988$ \\
LT40200501989019XXX02 & TM & $01 / 19 / 1990$ \\
LT40200501992129XXX02 & TM & $05 / 08 / 1992$ \\
LT50200501992297AAA02 & TM & $10 / 23 / 1992$ \\
LT50200501993035AAA02 & TM & $02 / 12 / 1993$ \\
LT50200501993347AAA03 & TM & $12 / 13 / 1993$ \\
LT50200501994094XXX02 & TM & $04 / 04 / 1994$ \\
LT50200501994302XXX02 & TM & $10 / 29 / 1994$ \\
LT50200501995081AAA02 & TM & $03 / 22 / 1995$ \\
LT50200501996052AAA03 & TM & $02 / 21 / 1996$ \\
LT50200501996084XXX02 & TM & $03 / 24 / 1996$ \\
LT50200502001145AAA02 & TM & $01 / 25 / 2001$ \\
LE502005012000023EDC00 & ETM+ & $01 / 23 / 2000$ \\
LE70200502010162EDC00 & ETM+ & $06 / 11 / 2010$ \\
LE70200502010210ASN00 & ETM + & $07 / 29 / 2010$
\end{tabular}

(GTM) coordinate system, which is the coordinate system in which the original orthophotos were referenced. This system uses a WGS84 datum, false easting: 500,000 m, false northing: $0 \mathrm{~m}$, central meridian: $-90.5^{\circ}$, scale factor: 0.9998 , and origin latitude: $0 \mathrm{~m}$. Each unit was digitized as a polygon and stored as an independent shapefile with a unique ID. A schematic diagram showing the methodology used to create the polygons from all sources of data is shown in Figure 2. For all digitized units the start and end dates of the eruption were also compiled, as was an estimate of the mean thickness of each unit (see below).

The planimetric length of the flows was measured individually for each flow using the distance measuring tool in ArcMap ${ }^{\circledR}$; these lengths were then recorded in the attribute table of the shapefile and in a Microsoft Excel spreadsheet. The planimetric areas of the polygons that represent each of the lava flow units was calculated using the "surveyor's area formula" (Braden, 1986), which was coded in Matlab ${ }^{\circledR}$ to automate the process. The surface areas were calculated using the slope values of a raster data set derived from a digital elevation model of the region. The area of each polygon was divided into pixels, corresponding to the pixels in the slope raster data set. The planimetric areas from each pixel in each polygon were projected onto a plane surface with a slope given by the slope of the pixel in the corresponding slope raster data set, i.e., dividing the planimetric area of the pixel by the cosine of the slope angle. The calculation was done on a pixel by pixel basis for each polygon.

A set of elevation contours in digital format generated by the Guatemalan National Geographic Institute (Instituto Geográfico Nacional, IGN), in conjunction with the Japanese International Cooperation Agency (JICA), was also used. This elevation contour data set has an elevation interval of $10 \mathrm{~m}$, and was generated
Figure 2. Process diagram of the methodology used to generate the polygons for the different geological units. An equivalent diagram applies to the process of generation of the points corresponding to eruptive vents.

\section{Photographs}

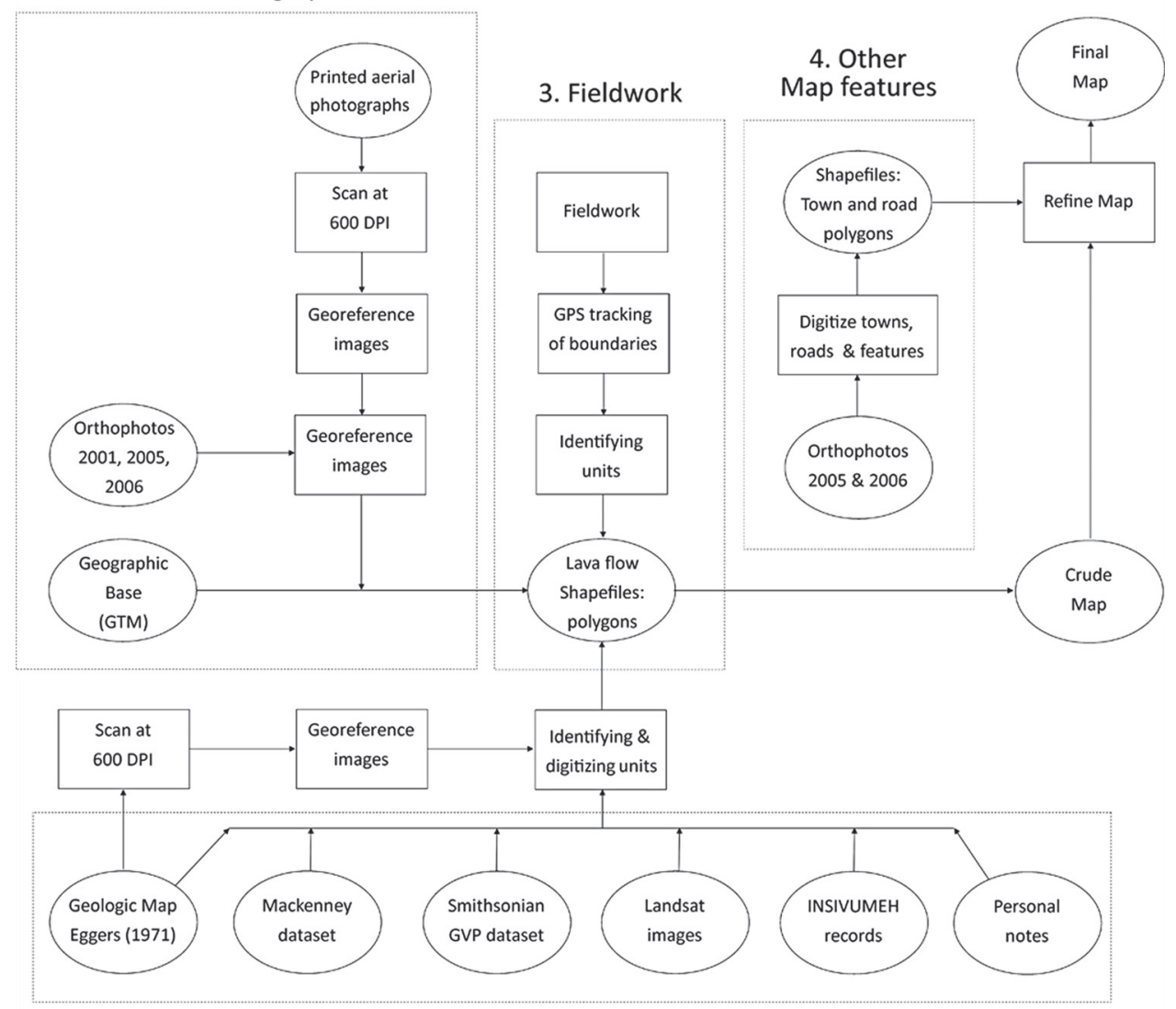

2. Descriptive information 
by photogrammetric methods from aerial photographs acquired in 2000. In this work, the contours were used to interpolate a DEM with a horizontal resolution (pixel size) of $5 \mathrm{~m}$. Accessory electronic GIS files for the final map were also derived from this DEM, specifically the hillshade and contour layers.

Descriptive information that did not provide a direct "mappable" data set was analyzed and interpreted, mainly based on acquaintance with Pacaya's morphology and activity, and used in the creation of the polygons. Most of the polygons between 1965 and 1971 were built from the drawings and descriptions by A. Mackenney, who describes the location of the vents on the flanks, the base, or the summit crater area. The same source gives the direction of flows with respect to the vent, and further interpretation of the length of the flows is done based on the drawings. From 1971 to 1982, the data sets include the scanned aerial photographs, and some other descriptive sources like the unpublished work of A. Mackenney (2009, personal commun.), and the reports of the Global Volcanism Program. The trajectory and length of the flows were estimated based on the description of the most distant point reached with respect to the base of the volcano. The descriptions give the widths of many flows, but thicknesses are rarely mentioned. Descriptive information was also used to build polygons for units emplaced from 1986 onward, mainly using information provided by OVPAC, with ancillary data from the Global Volcanism Program. In these cases the lengths were estimated "by sight" in the field, checking when possible with aerial orthophotography and scanned and georeferenced aerial photography. The thicknesses were also estimated based on judgment and experience with similar measured flows, considering that flows on steeper slopes near the summit area tend to be much thinner than flows on the flatter terrains on the base of the cone and beyond.

\section{MULTIPLE MAPS}

A total of 249 lava flow units was identified and digitized, as well as six pyroclastic flow deposits, two scoria units, two undivided pyroclastic units (proximal and distal), one aeolian sediment unit, and one alluvium unit. The spreadsheet in Appendix A compiles the unit label, dimensions (length, area, estimated thickness, and volume), dates, and mean effusion rate for all lava flows. Additionally, 349 eruptive vents associated with mapped units, emplaced between 1961 and 2010, were identified and digitized. Appendix B shows the locations and activity dates for the eruptive vents.

The volcanological map of Volcán de Pacaya with all the units exposed on the surface in 2010 is presented in Appendix C. This map includes 34 lava flow units, of aa and pahoehoe type, all porphyritic basalt. Of these, 26 were emplaced before the 18 September 1998 eruption, and are covered by a layer of fallout ash and fine-grained aeolian deposits up to $30 \mathrm{~cm}$ thick. The lava flows emplaced between 2004 and 2010 are only partially covered by tephra. Most of the 249 lava flows that occurred in the 1961-2000 eruptive period are now covered by younger units.
The 1961-2010 map also includes geologic units that are not lava flows. Three pyroclastic flow deposits emplaced in 1993, 1995, and 2009 are included. The deposits from 1993 and 1995 are partially exposed at their distal facies. The map includes one aeolian deposit generated by reworking of the ash fall and other pyroclastic deposits. There is also one alluvium unit mapped in the channel of El Chupadero River, tributary to the Metapa River. Seven additional maps were created at approximate 5-10 year intervals: 1961-1969, 1970-1979, 1980-1984, 1985-1989, 1990-1994, 1995-1999, and 2000 (see Appendix D). The 2000 map exhibits the distribution of lava flows and pyroclastic material dispersed during a Hawaiian to Strombolian-type eruption, which included two lava fountains in 16 January and 29 February 2000. Each one of these maps, which also include the distribution of flows from previous years, is a snapshot in time of the activity and geology of Pacaya. Altogether, they depict the growth and evolution of this young stratovolcano of basaltic composition. In order to facilitate the analysis of these data by other researchers, the complete data set compiled in a GIS in ESRI shapefile format (generated in ArcGIS-version 9.3) is included in Appendix E.

\section{SPATIO-TEMPORAL VARIATIONS}

The lava flows at Pacaya are all similar in morphology and texture, ranging from aa to pahoehoe. Lava flow lengths range from $30 \mathrm{~m}$ to $5.5 \mathrm{~km}$ (Fig. 3), areas between 80 and $1 \times 10^{6} \mathrm{~m}^{3}$, and volumes between 200 and $1 \times 10^{6} \mathrm{~m}^{3}$. For calculating the volume, the mean thicknesses of the majority of flows had to be estimated from descriptions made in the field, which resulted in a range between 0.5 and $7 \mathrm{~m}$. Lava flow thicknesses were estimated for each unit based on direct observations (although not measured) of lava flow thicknesses in the field, and should be considered a "best guess" estimated mean value for each unit. Thicknesses between 1.5 and $2 \mathrm{~m}$ were chosen for flows in high slopes $\left(>20^{\circ}\right)$, thicknesses between 2 and $2.5 \mathrm{~m}$ were chosen for intermediate slopes $\left(10^{\circ}\right.$ to $\left.20^{\circ}\right)$, and thicknesses greater than 2.5 were chosen for lower slopes $\left(<10^{\circ}\right)$.

The lengths of the Pacaya lava flows are generally less than 4 $\mathrm{km}$, with the exception of the flows emplaced in 1961 and 2010. They show a tendency of decreasing length with time (Fig. 3). The shorter length of the flows from 2006 to 2009 may be because flow extension was restricted by the topographic depression that existed at that time to the north of the Mackenney cone and south of the scarp. The flows of these dates are thicker for the same reason (locally reaching a thickness of $\sim 30 \mathrm{~m}$ ). Note that the long flow emplaced in 2010 (Hb10) originated at a vent outside the collapse scarp. The volumes of the lava flow units were calculated by multiplying the surface areas by the estimated thicknesses of each unit. The total cumulative volume of lava flows is $8 \times 10^{7} \mathrm{~m}^{3}$ (Fig. 4). The cumulative volume presented here is uncorrected for density and does not include products derived from collapsing lava flows, nor the scoria and ash volume that could have accumulated during the Strombolian activity, on the cone and other areas of the edifice. 
Figure 3. Length and time of emplacement of the lava flows.
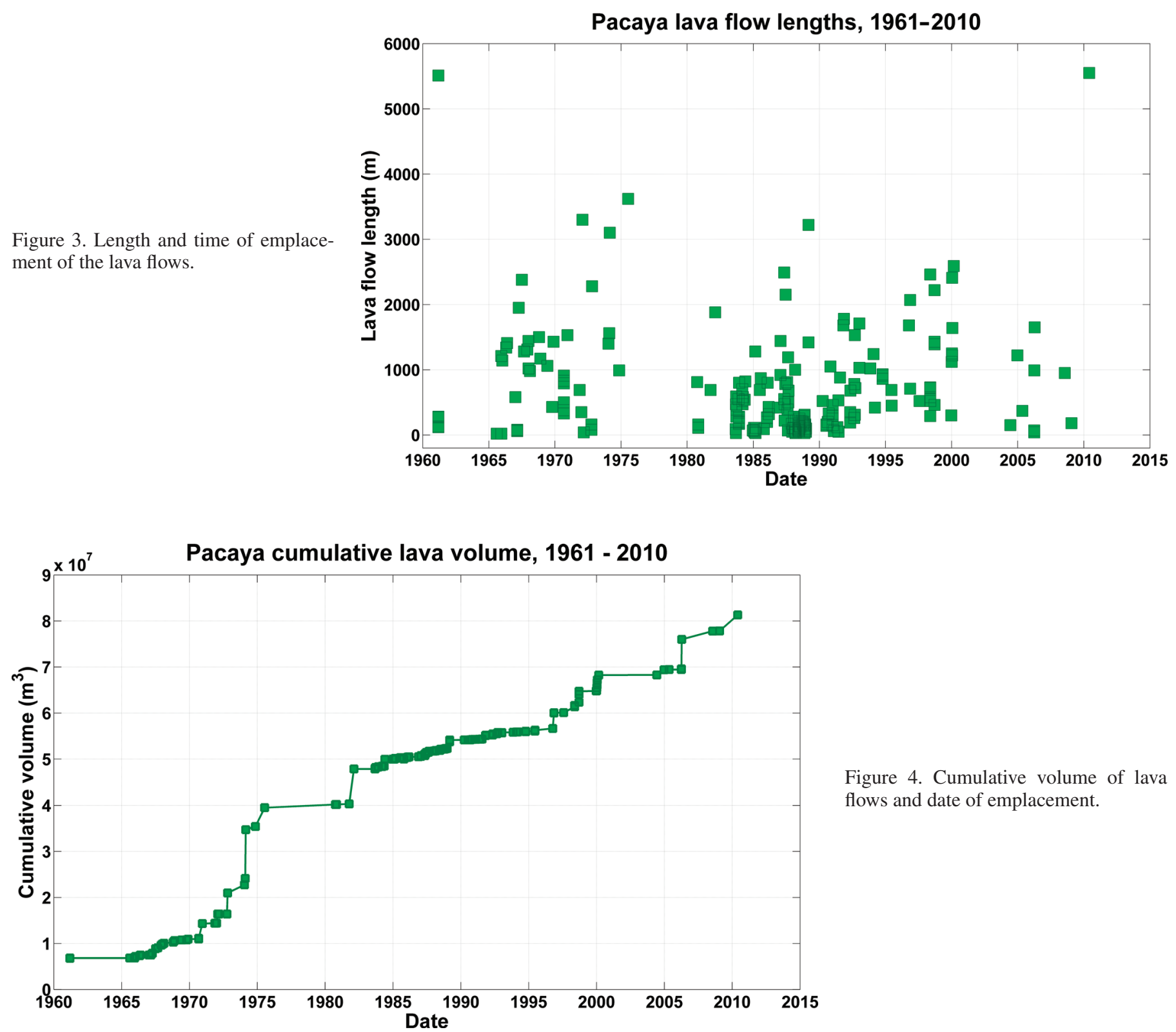

Figure 4. Cumulative volume of lava flows and date of emplacement.

Eruption rates were calculated by dividing the volumes by the emplacement time of each unit. Appendix A shows the results obtained from calculating lengths, areas, volumes, and eruption rates corresponding to the lava flow units.

\section{VENT DISTRIBUTIONS}

A total of 349 eruptive vents was identified and located. The technique for identifying and locating eruptive vents was based on criteria similar to those used to identify and delineate the polygons corresponding to geologic units. Each eruptive vent was digitized as a point, and all the points were stored in a single shapefile in ArcMap. The location of the majority of the eruptive vents is within a few hundred meters of the summit. Only a few are distributed on the flanks of the volcano (less than $5 \%$ are at elevations below $2200 \mathrm{~m}$ a.s.l.); these lower elevation vents include the ones that have produced many of the most voluminous flows (Fig. 5). There are more vents than lava polygons because eruptive vents may migrate as the lava is emplaced.

\section{PYROCLASTIC DEPOSITS}

There are 87 significant tephra dispersion events reported during this period at Pacaya. Four large tephra-fall deposits were studied and their volumes calculated. These deposits are associated with the explosive events of 27-31 July 1991, 11 November 1996, 20 May 1998, and 27 May 2010 (Fig. 6). Tephra volumes were calculated by two methods: an incremental method, which 


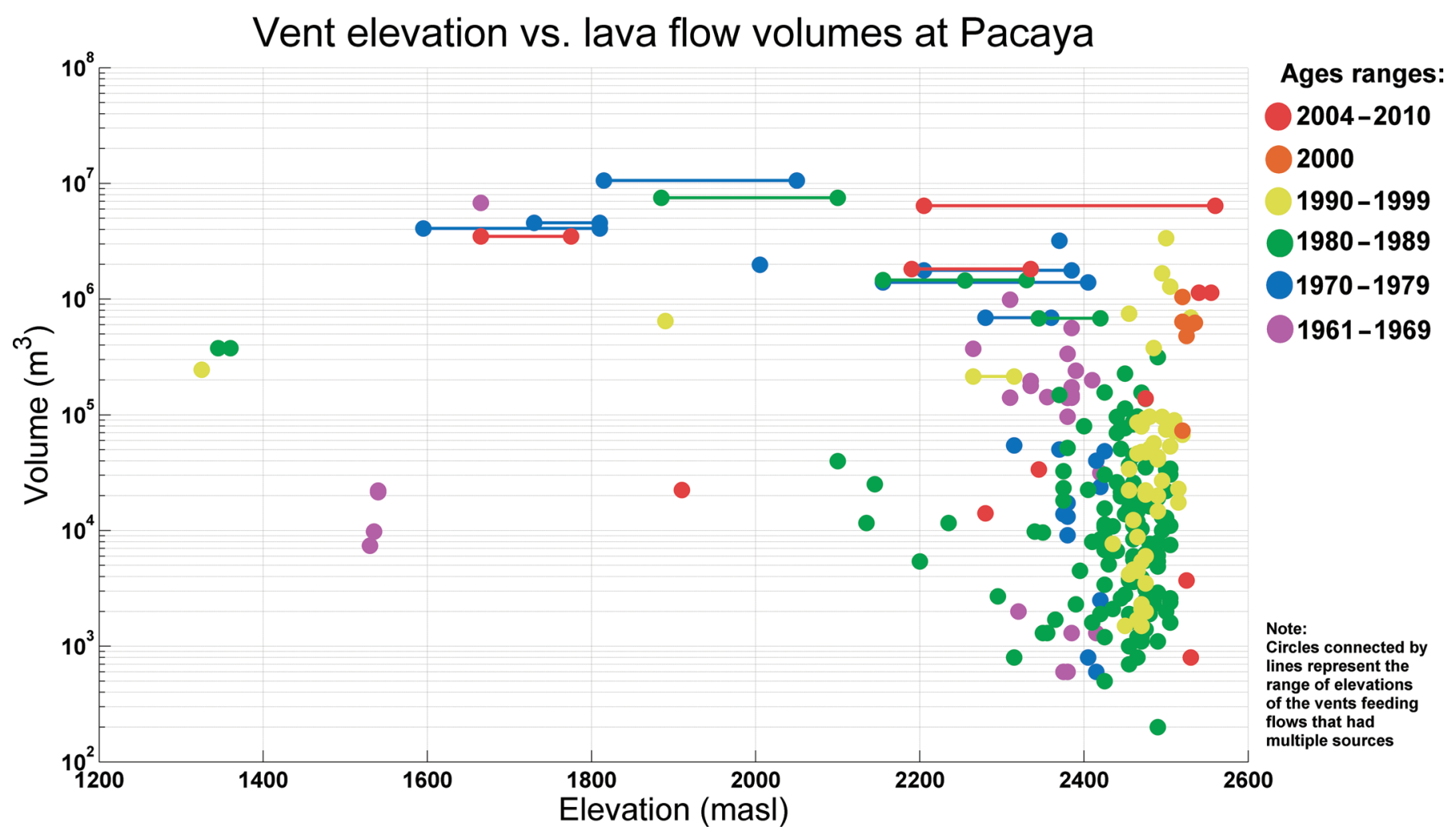

Figure 5. Volume of the lava flows and elevation of the eruptive vent.

sums the product of thickness of an isopach with the area enclosed, and the power law adjustment method, which potentially estimates additional volumes between and beyond isopachs. Volumes vary over an order of magnitude, from $1 \times 10^{6}$ to $1 \times 10^{7}$ (Table 4). These events dispersed tephra over hundreds of square kilometers and to distances of tens of kilometers. It is noteworthy that the explosive events of 1998 and 2010 sent the volcanic material toward the northeast, covering most of the capital city of Guatemala with ash (Fig. 6).

Other types of pyroclastic deposits include one from 2009 that resulted from the collapse of part of the active lava flow field on the southwest flank of Mackenney cone. This deposit exhibits big blocks of lava and a fine matrix, which was covered by a $2-5 \mathrm{~cm}$ layer of very fine ash. Two agglutinated scoria units associated with the eruptions of 16 January and 29 February 2000 were also mapped; these units border the flanks of the Mackenney and Pacaya cones (Appendix D.7). Units associated with the explosive eruption of 29 February 2000 include hot avalanche, pyroclastic flow, and tephra-/bomb-fall deposits.

\section{GEOCHEMISTRY AND PETROGRAPHY}

Thirty rock samples were collected during the 2009 field campaign, which correspond to units emplaced between 2000 and 2009. Chemical analysis for major and trace elements were done for 14 of these samples, using X-ray fluorescence (XRF) and inductively coupled plasma-mass spectrometry (ICP-MS) at the Michigan State University geochemistry laboratory. These new chemical analyses were combined with previous whole rock geochemical analyses from a variety of published sources to allow a comparison of rocks erupted throughout the 1962 to 2009 period. All these data are presented in Appendix E.

The Pacaya lavas are high alumina basalts. The rocks are geochemically monotonous, with $\mathrm{SiO}_{2}$ contents between 50 and $52.5 \mathrm{wt} \%$, and $\mathrm{MgO}$ contents between 3 and $5 \mathrm{wt} \%$ (Fig. 7). The lavas usually host plagioclase, olivine, and opaque phenocrysts (Bardintzeff and Deniel, 1992; Conway, 1995). The composition has remained relatively similar during the present eruptive period, since 1961, and this composition is also similar to previous lavas from this volcano (Eggers, 1971). There is a slight variation of $\mathrm{CaO}$ in this group of lavas, which suggests a phenocryst enrichment or depletion (Fig. 8).

\section{DISCUSSION AND CONCLUSIONS}

The mapping of units emplaced due to the activity of Volcán de Pacaya between 1961 and 2010 includes 249 lava flow units and 349 associated eruptive vents. The eruptive styles of the activity that resulted in the emplacement of these units ranges from purely effusive to moderately explosive Strombolian and Hawaiian (lava fountaining) activity. The predominant type of mapped unit is basaltic lava flows, which vary in their typology from aa to 

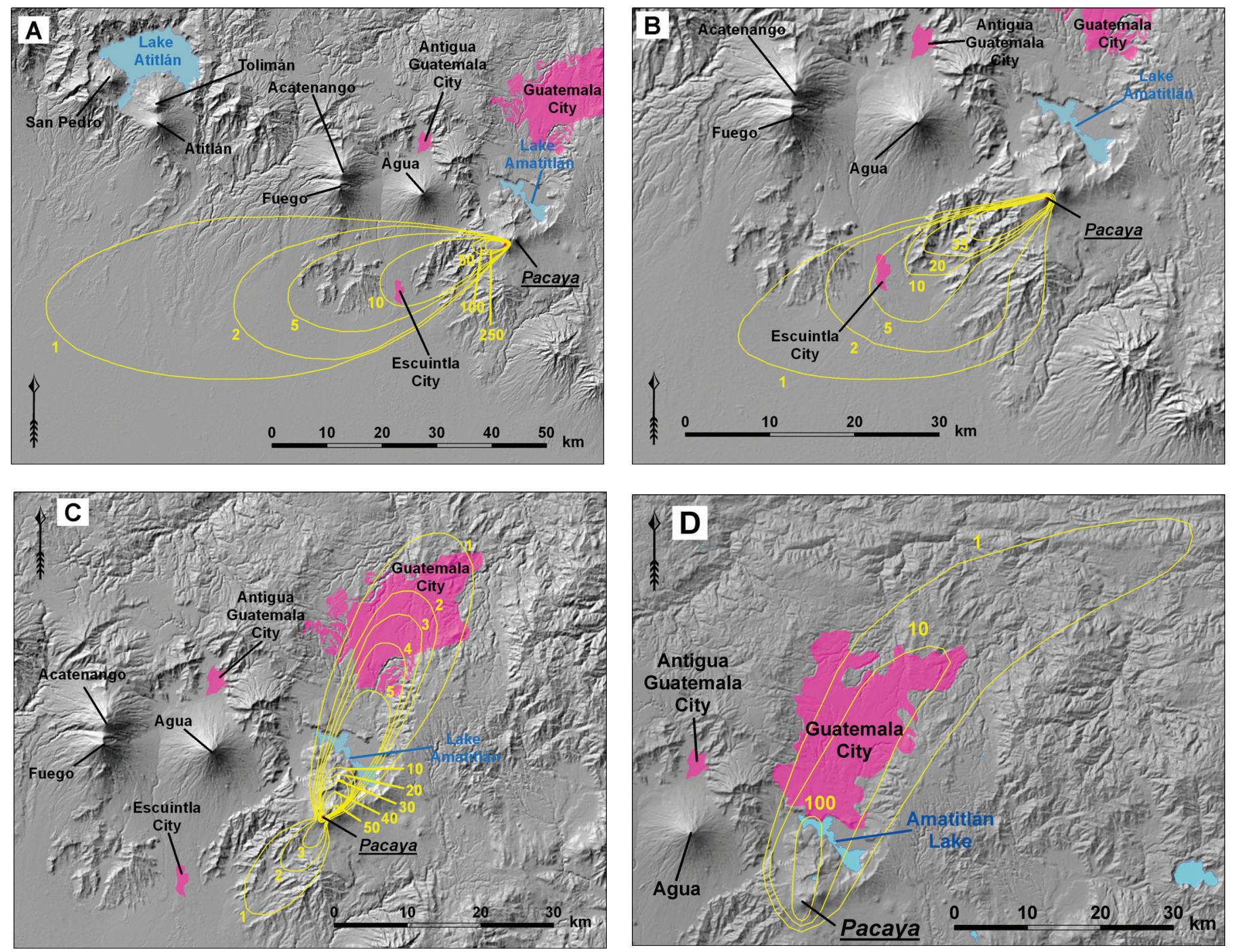

Figure 6. Isopach maps associated with the events of 27-31 July 1991 (A), 11 November 1996 (B), 20 May 1998 (C), and 27 May 2010 (D). The values of the isopachs (in yellow) are given in $\mathrm{mm}$. The names of other volcanoes and populated centers (in pink), as well as the lakes (in blue) are also given.

pahoehoe. These flows are commonly erupted over prolonged periods of time that can last several years and may be marked by the absence of significant explosive activity. The low-level Strombolian "open vent" activity of Pacaya can be maintained over prolonged periods of time, due in part to the physical and chemical characteristics of the magmas. The magmas have had a similar composition since 1961, i.e., high alumina basalts. However, significantly violent explosive eruptions have recurred also at times at Pacaya, although their products have been dispersed over a much wider area, mainly as tephra falls, and therefore are not as well represented in our series of maps.

During the eruptive period from 1961 to 2009, the eruptions were restricted to the collapse amphitheater from the Old Pacaya; however, the flows that formed the extensive lava flow field after the 27 May 2010 eruption had source vents situated outside the

\begin{tabular}{lcc}
\multicolumn{3}{c}{$\begin{array}{c}\text { TABLE 4. TEPHRA VOLUMES PRODUCED BY } \\
\text { LARGER EXPLOSIVE ERUPTIONS }\end{array}$} \\
\hline \hline & $\begin{array}{c}\text { Volume by the } \\
\text { incremental method } \\
\left(\mathrm{m}^{3}\right)\end{array}$ & $\begin{array}{c}\text { Volume by the power } \\
\text { law fitting method } \\
\left(\mathrm{m}^{3}\right)\end{array}$ \\
Eruption date & $1.0 \times 10^{7}$ & $7.6 \times 10^{7}$ \\
\hline 27-31 July 1991 & $6.0 \times 10^{6}$ & $1.8 \times 10^{6}$ \\
11 November 1996 & $3.0 \times 10^{6}$ & $1.6 \times 10^{6}$ \\
20 May 1998 & $8.5 \times 10^{6}$ & $1.3 \times 10^{7}$ \\
27 May 2010 & &
\end{tabular}

collapse amphitheater. The main concern for the population living in the surroundings of the volcano has been the fall of ash and ballistic bombs, with minor concerns related to lava flow during more explosive eruptions. With the exception of a few short flows that were probably erupted within the last few centuries, it wasn't until 2006 that the first lava flows were able to cross the rim of 

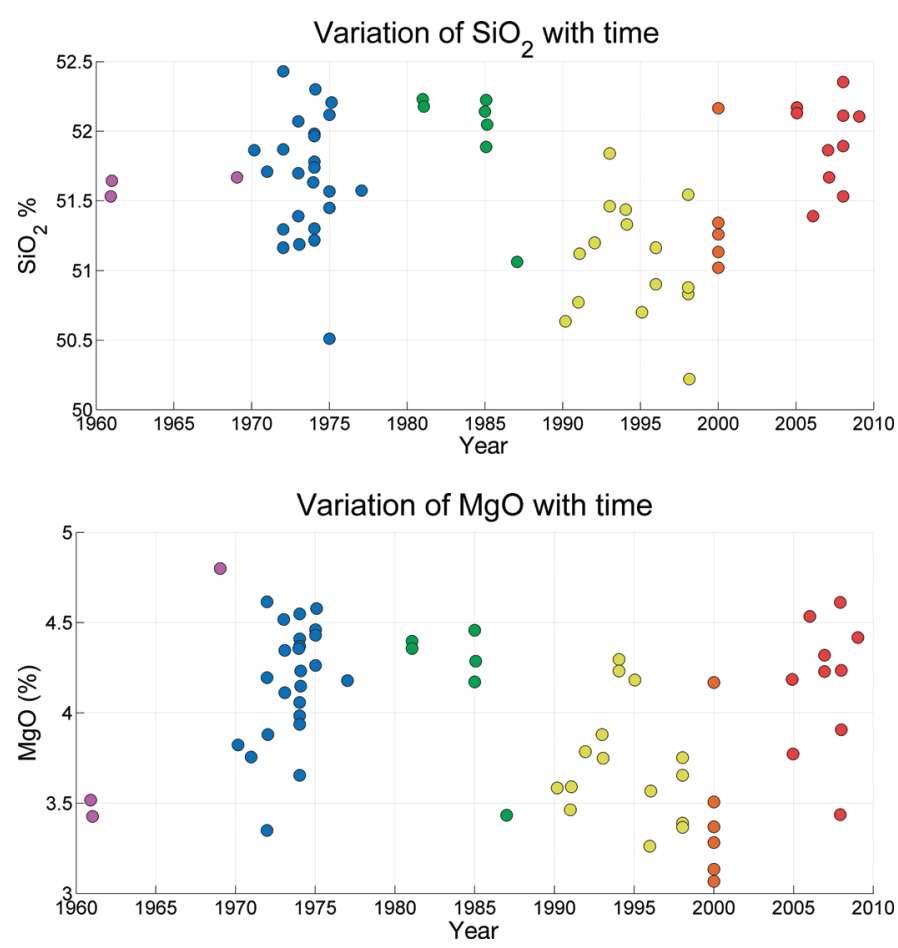

Figure 7. $\mathrm{SiO}_{2}$ and $\mathrm{MgO}$ wt\% variations with age for Pacaya lavas. Colors are keyed to ages as follows: purple $=1960 \mathrm{~s}$, blue $=1970 \mathrm{~s}$, green $=1980$ s, yellow $=1990$ s, orange $=2000$, and red $=2003$ to 2009 . Precision for these X-ray fluorescence analyses are similar to the size of the points, while accuracy is less than $1 \mathrm{wt} \%$ of the amount determined.

the collapse structure from Old Pacaya, moving northward on the plain known as "La Meseta." If this effusive tendency continues for the long term toward the north-northwest flanks, the lavas could eventually threaten the communities of San Francisco de Sales, San José Calderas and El Cedro, and San Vicente Pacaya. With respect to the populated centers to the south and southwest, large lava flows (like the 1961 "Cachajinas" flow or the June 2010 flows) issued from the base of the southwest and south flanks could reach the towns of El Patrocinio, El Rodeo, and El Caracol. The flows erupted from the southeast flank during June 2010 destroyed a few houses and threatened to reach some communities (e.g., Los Pocitos), but changed direction following the topographic gradient and remained confined to the channel of the Chupadero river, for the rest of their trajectory.

Although it is more possible than probable, the generation of pyroclastic flows and similar processes (e.g., incandescent avalanches) associated with explosive activity from the volcano, especially during the most violent Strombolian eruptions, could be hazardous for the people who are located closest to the eruptive vent. It is also important to be aware of the possibility of cone collapse of Pacaya. The current Mackenney cone and the remnants of modern Pacaya may be fed by a high-level magma chamber. The possibility of collapse, enhanced by the presence of such a shallow magma body, must be considered in future hazard research.
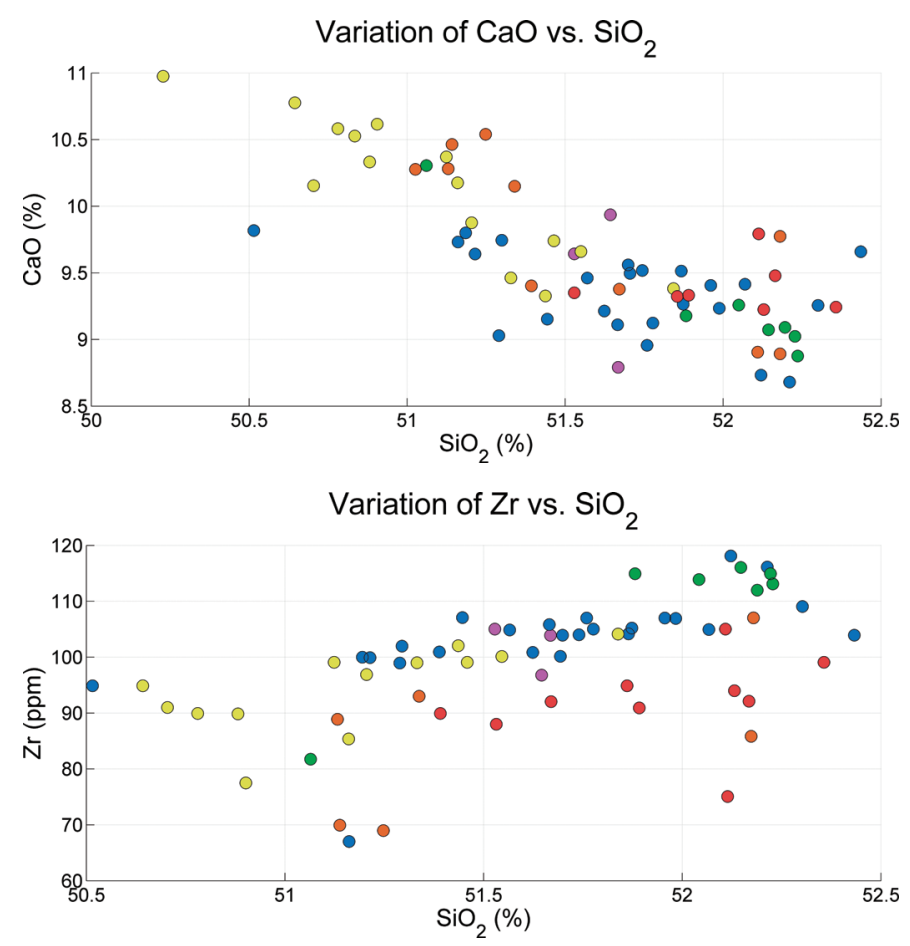

Figure 8. $\mathrm{CaO}\left(\mathrm{wt} \%\right.$ ) and $\mathrm{Zr}(\mathrm{ppm})$ plotted vs. $\mathrm{SiO}_{2}(\mathrm{wt} \%$ ) for Pacaya lavas. Colors are keyed to ages as follows: purple $=1960 \mathrm{~s}$, blue $=$ 1970 s, green $=1980$ s, yellow $=1990$ s, orange $=2000$, and red $=2003$ to 2009. Slight covariation that could be explained by plagioclase phenocryst concentration/depletion is noted.

\section{CONCLUSION}

This work presents a unique data set of lava flow units, pyroclastic deposits, and vent distribution that describes the spatial and temporal evolution (thus 3D) of the activity at Volcán de Pacaya in Guatemala from 1961 to 2010. Data sources for this work include aerial photographs (orthorectified and non-orthorectified), Landsat satellite images, field notes, sketches, maps, and reports and bulletins generated and gathered systematically and occasionally by various people and institutions during this period of activity. The information is processed and integrated in a geographic information system, and is available here in the form of maps and spreadsheets for other researchers to use.

\section{ACKNOWLEDGMENTS}

Preparation of these maps depends on regular observations. We dedicate this effort to Dr. Alfredo Mackenney, who has visited Pacaya regularly and shared his extensive observations. Don Swanson prepared a detailed review of the maps and text, which helped us greatly. Financial support for this work came from the U.S. National Science Foundation, PIRE 0530109. 


\section{APPENDIX A}

Excel spreadsheet with the label of the unit, dimensions (length, area, thickness, volume), and mean volume flow rate of all lava flows.

\section{APPENDIX B}

Excel spreadsheet with the location and activity date of all the eruptive vents.

\section{APPENDIX C}

Complete map with the 1961-2010 activity.

\section{APPENDIX D}

Seven maps showing the deposits in different periods:
D.1. 1961-1969,
D.2. 1970-1979,
D.3. 1980-1984,
D.4. 1985-1989,
D.5. 1990-1994,
D.6. 1995-1999,
D.7. 2000, and
D.8. 1961-2010.

\section{APPENDIX E}

Multiple GIS files in ArcGIS (ESRI) format, including all the mapped units and vents (shapefiles) and the final map documents (.mxd files), grouped in a single .zip file.

\section{APPENDIX F}

Video file in .wmv format showing the progressive emplacement of lava flows and vent openings throughout the 1961-2010 period on Pacaya volcano.

\section{REFERENCES CITED}

Bardintzeff, J.-M., and Deniel, C., 1992, Magmatic evolution of Pacaya and Cerro Chiquito volcanological complex, Guatemala: Bulletin of Volcanology, v. 54, no. 4, p. 267-283, doi:10.1007/BF00301482.

Braden, B., 1986, The surveyor's area formula: The College Mathematics Journal, v. 17, p. 326-349, doi:10.2307/2686282.

Conway, F.M., 1995, Construction patterns and timing of volcanism at the Cerro Quemado, Santa Maria, and Pacaya volcanoes, Guatemala [Ph.D. thesis]: Houghton, Michigan Technological University, 304 p.

Conway, F.M., Diehl, J.F., and Matías, O., 1992, Paleomagnetic constraints on eruption pattern at Pacaya composite volcano, Guatemala: Bulletin of Volcanology, v. 55, p. 25-32, doi:10.1007/BF00301117.

Eggers, A.A., 1971, The geology and petrology of the Amatitlán quadrangle, Guatemala [Ph.D. thesis]: Hanover, New Hampshire, Dartmouth College, 221 p.

Escobar Wolf, R.P., Matías Gomez, R.O., and Rose, W.I., 2009, Notes on a New Geologic Map of Santiaguito Dome Complex, Guatemala: Geological Society of America Digital Map and Chart Series, v. 8, doi:10.1130/2010 .DMCH008.

Kitamura, S., and Matías, O., 1995, Tephra stratigraphic approach to the eruptive history of Pacaya volcano, Guatemala. Science Reports-Tohoku University, Seventh Series: Geography (Sheffield, England), v. 45, no. 1, p. 1-41.

Mann, P., Rogers, R., and Gahagan, L.M., 2007, Overview of plate tectonic history and its unresolved tectonic problems, in Bundschuh, J., and Alvarado, G., eds., Central America: Geology, Resources and Hazards (vol. 1): London, Taylor \& Francis, p. 201-237.

Scott, W., 1989, Volcanic-hazards zonation and long-term forecasts, in Tilling, R.I., ed., Volcanic Hazards, Short Course in Geology (vol. 1): Washington, D.C., American Geophysical Union, 123 p.

Vallance, J.W., Siebert, L., Rose, W.I., Girón, J.R., and Banks, N.G., 1995, Edifice collapse and related hazards in Guatemala: Journal of Volcanology and Geothermal Research, v. 66, no. 1-4, p. 337-355, doi:10.1016 /0377-0273(94)00076-S.

Venzke, E., Wunderman, R.W., McClelland, L., Simkin, T., Luhr, J.F., Siebert, L., Mayberry, G., and Sennert, S., eds., 2009, Global Volcanism, 1968 to the Present. Smithsonian Institution, Global Volcanism Program Digital Information Series, GVP-4; http://www.volcano.si.edu/reports/ (accessed December 2009).

Witham, C., 2005, Volcanic disasters and incidents: A new database: Journal of Volcanology and Geothermal Research, v. 148, p. 191-233, doi:10.1016 /j.jvolgeores.2005.04.017.

Accepted 26 SePtember 2011 